Ерғали Айғаным, $\mathrm{PhD}$ доктор

Казахский национальный аграрный университет

г Алматы, Республика Казхахстан

E-mail: regetta88@mail.ru

ORCID ID 0000-0003-2863-5123

\title{
КАДАСТРОВАЯ ОЦЕНКА ЗЕМЕЛЬ СЕЛЬСКОХОЗЯЙСТВЕННОГО НАЗНАЧЕНИЯ
}

Yergali Aiganym, PhD doctor Kazakh National Agrarian University Almaty, the Republic of Kazakhstan

E-mail: regetta88@mail.ru

ORCID ID 0000-0003-2863-5123

\section{CADASTRAL ASSESSMENT OF AGRICULTURAL LANDS}

Annotaion: In the Republic of Kazakhstan, regulatory assessment of land plots is applied. This is not suitable for many professionals; therefore, some of them believe that in Kazakhstan the method of determining the estimated value is imperfect and needs to be improved. Therefore, other specific methods are being developed that are applicable only to Kazakhstani conditions. But they have not yet become widespread in our country.

Keywords: The purpose of cadastral valuation is a one-time definition of the cadastral value of all land plots within the boundaries of administrative and territorial entities (regions, districts, cities, cities, etc.). In accordance with the assessment zones on a specific date.

Аннотация: В Республике Казахстан применяется нормативная оценка земельных участков. Многих специалистов это не устраивает, поэтому некоторые из них считают, что в Казахстане методика определения оценочной стоимости несовершенна и требует доработки. Поэтому в настоящее время разрабатываются и другие специфические методы, применимые только для Казахстанских условий. Но они пока не получили широкого применения в нашей стране.

Ключевые слова: Целью кадастровой оченки является единовременное определение кадастровой стоимости всех земельных участков в границах административнотерриториальных образований (областей, районов, городов, поселков и т.n.) по оценочным зонам на определенную дату.

Казахстан располагает крупнейшими земельными ресурсами. Общая площадь земельного фонда составляет 272 млн. гектар. В связи с этим земельные отношения в Казахстане - очень интересный и актуальный вопрос. Объектом земельных отношений является вся земля в пределах территории Республики Казахстан, отдельные земельные участки независимо от того, что на них расположено и от правовых оснований их закрепленности за отдельными субъектами, а также право на земельные участки и земельные доли.

Земельные отношения в Казахстане складываются достаточно давно. Довольно долго проводились земельные реформы, которые в дальнейшем будут рассмотрены, и на данный момент Правительством Республики Казахстан рассмотрен и принят в 2003 году 
новый Земельный Кодекс. В настоящий момент земельные отношения в Казахстане строятся на Земельном кодексе, на основе Конституции Республики Казахстан и на основе нормативно-правовых актов, принимаемых в стране. Также в Казахстане существует множество Постановлений Правительства Республики Казахстан, утверждающих земельные отношения, ставки платы за землю, порядок определения оценочной стоимости земельных участков и т.д.

Законодательные акты издаются в Республике Казахстан для того, чтобы установить основания, условия и пределы возникновения, изменения и прекращения права собственности на земельный участок и права землепользования, порядка осуществления прав и обязанностей собственников земельных участков и землепользователей, регулирования земельных отношений в целях обеспечения рационального использования и охраны земель, воспроизводства плодородия почв, охраны прав на землю физических, юридических лиц и государства, создания и развития рынка недвижимости, укрепления законности в области земельных отношений. Но об этом подробнее поговорим в первой главе Дипломной работы, которая посвящена, помимо основных положений оценки земли, вопросам правового регулирования земельных отношений в Казахстане. Узнаем, какие новшества были введены в связи с новым Земельным кодексом. По Земельному кодексу Республики Казахстан от 20 июня 2003 года №442 - II землями сельскохозяйственного назначения обозначены земли, предоставленные для нужд сельского хозяйства и предназначенные для этих целей.

В составе земель сельскохозяйственного назначения выделяются сельскохозяйственные угодья и земли, занятые внутрихозяйственными дорогами, коммуникациями, замкнутыми водоемами, мелиоративной сетью, постройками и сооружениями, необходимыми для функционирования сельского хозяйства, а также прочие угодья. Сельскохозяйственные угодья подлежат особой охране. Использование этих земель в целях, не связанных с сельскохозяйственным производством, допускается в исключительных случаях.

К сельскохозяйственным угодьям относятся: пашня, залежь, земли, занятые многолетними насаждениями, сенокосы и пастбища. Сельскохозяйственные угодья могут быть орошаемые и неорошаемые. К орошаемым сельскохозяйственным источникам относятся земли, пригодные для сельскохозяйственного использования и полива, имеющие постоянную или временную оросительную сеть, связанную с источником орошения, водные ресурсы которого обеспечивают полив этих земель стоком не ниже $75 \%$ обеспеченности в оптимальные сроки по проектным или действующим нормативам оросительных норм при существующем коэффициенте полезного действия системы.

В Республике Казахстан земли сельскохозяйственного назначения могут предоставляться:

- в частную собственность гражданам Республики Казахстан для развития личного подсобного хозяйства, садоводства и дачного строительства;

- в частную собственность или землепользование физическим и юридическим лицам Республики Казахстан для ведения крестьянского (фермерского) хозяйства, товарного сельскохозяйственного производства, лесоразведения, научно-исследовательских, опытных и учебных целей, ведения подсобного сельского хозяйства, огородничества и животноводства;

- иностранцам и лицам без гражданства во временное землепользование на условиях аренды сроком до 10 лет.

В целях государственного контроля за качеством сельскохозяйственных угодий, передаваемых в землепользование и собственность гражданам и юридическим лицам, 
составляется паспорт земельных участков сельскохозяйственного назначения на основании данных материалов почвенных, почвенно-мелиоративных, геоботанических обследований и бонитировки почв за счет средств республиканского бюджета.

Предоставление земельных участков из государственной собственности в частную производится на возмездной основе путем продажи единовременно либо в рассрочку по решению местного исполнительного органа, за исключением случаев, когда земельный участок предоставляется безвозмездно.

Плата за возмездное предоставление (продажу) в собственность земельных участков или плата за продажу права аренды исчисляется на основе кадастровой (оценочной) стоимости, рассчитываемой по базовым ставкам платы за земельные участки с применением поправочных коэффициентов.

При изменении целевого назначения земельного участка, безвозмездно предоставленного для ведения личного домашнего (подсобного) хозяйства, садоводства, индивидуального жилищного и дачного строительства, собственник земельного участка обязан выплатить в доход местного бюджета сумму, равную кадастровой (оценочной) стоимости земельного участка, предусмотренной законодательством Республики Казахстан для изменения целевого назначения.

По Налоговому кодексу базовые налоговые ставки на земли сельскохозяйственного назначения, предоставленные физическим лицам для ведения личного домашнего (подсобного) хозяйства, садоводства и дачного строительства, включая земли, занятые под постройки, устанавливаются в следующих размерах:

1) При площади до 0,50 га включительно - 20 тенге за 0,01 га.

2) На площадь, превышающую 0,50 га, - 100 тенге за 0,01 га.

При определении кадастровой (оценочной) стоимости земельных участков, предоставляемых государством для ведения сельскохозяйственного производства, применяются поправочные коэффициенты (повышающие или понижающие) в зависимости от качественного состояния земельного участка, его местоположения, водообеспеченности, а также от удаленности этих участков от центров сферы обслуживания в соответствии с Земельным кодексом Республики Казахстан.

Поправочные (повышающие, понижающие) коэффициенты и границы зон в городах районного значения, поселках и сельских населенных пунктах утверждаются решением районного представительного органа, а в городах областного значения (городах Астане и Алматы) - областным представительным органом. При этом максимальный размер поправочного коэффициента не должен превышать двукратный размер.

Схемы зонирования земель разработаны согласно «Рекомендации по составлению районной схемы зонирования земель для целей налогообложения», утвержденной Агентством Республики Казахстан по управлению земельными ресурсами от 25.06.2002 г. Зонирование земель на территории районов проводилось по кадастровым кварталам и сельским населенным пунктам. В результате проведенных расчетов были разработаны зональные коэффициенты, необходимые для определения зон для налогообложения.

Повышение качества выполняемых работ решается через комплекс организационнотехнических предприятий, включающих в себя распределения обязанностей и ответственность исполнителей и руководителей за качество выпускаемой продукции, форм нормальной и материальной заинтересованности в итогах труда, а также в постоянном и текущем контроле полевых и камеральных работ.

В технологическом процессе работ используется современная компьютерная техника с внедрением программного обеспечения при решении задач в делопроизводстве. 
Руководителями подразделений периодически производятся текущие проверки работ и их приемка.

Оценку земель сельскохозяйственного назначения госпредприятие производит следующим образом.

Переход к рыночной экономике изменил все, в том числе и земельно-правовые отношения. Буквально за последние несколько лет была принята масса Указов, Постановлений Президента и Правительства, но с течением времени все стареет и стареет, и хотелось бы, чтобы земельные отношения все-таки были полностью урегулированы. Может, когда-нибудь для достоверной оценки будут использоваться все три метода оценки земли.

И в заключении я бы хотела сказать, что плата за землю, а соответственно и оценка земли - довольно молодая тема. Поэтому я считаю, что надо не только развивать эту тему, но и заниматься поднятием правовой грамотности населения. Заинтересовывать людей быть созидателями на земле.

\section{ЛИТЕРАТУРА}

1. Земельный кодекс Республики Казахстан от 20 июня 2003 года №442-II.

2. Закон Республики Казахстан «О земле» от 24 января 2001 г. №152 - II ЗРК.

Продолжение

3. Указ Президента Республики Казахстан от 25 декабря 1995 г. №2717, имеющий силу Закона «О государственной регистрации прав на недвижимое имущество и сделок с ним».

4. Постановление Правительства Республики Казахстан от 2 сентября 2003 года №890 «Об установлении базовых ставок платы за земельные участки при их предоставлении в частную собственность, при сдаче государством или государственными землепользователями в аренду, а также размера платы за продажу права аренды земельных участков».

5. АгроИнформ - информационно-аналитический бюллетень Министерства сельского хозяйства Республики Казахстан №2 июнь, 2002 г.; январь №1, март №3, апрель №4, 2003 г.

6. АльПари №3-4, 2016 г. «Экономическая оценка сельскохозяйственных угодий с использованием экономико-математических моделей».

7. Отчет по разработке базовых ставок платы за земельные участки./ Агентство Республики Казахстан по управлению земельными ресурсами Государственный научнопроизводственный центр по землеустройству. Астана, 2017 г. 